\title{
Caracterización petrofísica de las areniscas utilizadas en la construcción del Conjunto Monumental de Ciudad Rodrigo, Salamanca. España
}

\author{
Petrophysical characteristics of the sandstones used in the \\ construction of the Monumental Heritage of Ciudad Rodrigo, \\ Salamanca. Spain
}

\author{
M. J. VARAS ${ }^{(*)}(* *) ;$ E. MOLINA ${ }^{(* * *)} ;$ M. A. VICENTE ${ }^{(* *)}$

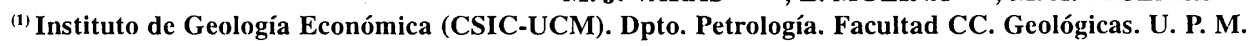 \\ ${ }^{(* *)}$ I.R.N.A-C.S.I.C. \\ (**) Dpto. Geología. Universidad de Salamanca \\ (*) Unidad Asociada (Universidad de Salamanca-CSIC)
}

Fecha de recepción: 8-V-02

Fecha de aceptación: 10-VII-02

ESPAÑA

\section{RESUMEN}

El conocimiento de las características petrofísicas de las piedras con las que se va a trabajar; supone ahorrar esfuerzos y futuros disgustos a la hora de valorar los resultados tanto en las propias intervenciones de restauración como en la edificación. Pero si además, estas piedras son areniscas, como es nuestro caso, este conocimiento es mucho más necesario, por tratarse de materiales pétreos blandos y porosos. En el presente trabajo se hace un exhaustivo estudio de las propiedades petrofísicas que presentan las areniscas utilizadas en la construcción del Conjunto Monumental de Ciudad Rodrigo (Salamanca).

Se han empleado cinco variedades distintas de arenisca: Roja, Marrón, Rayada, Nodular y' Blanca, según el grado de transformación diagenética que sufren. Cada una de ellas tiene importantes diferencias mineralógicas, texturales y. estructurales con relación a las demás, lo que implica un diferente comportamiento como material de construcción. La variedad Roja es la menos transformada y, por ello, la menos apta para la construcción. Por el contrario, la variedad Blanca es la que mayor grado de diagénesis tiene y la que mejores aptitudes presenta para este fin.

\section{SUMMARY}

Knowledge of the petrophysical characteristics of stones used in construction is evidently advantageous in the sense that it can help avoid wasting time and future disappointments when attempting to assess the results both in restoration work and in actual construction work. However, if the material used is sandstone, as in the case addressed here, such knowledge is even more pertinent since such materials are soft and porous. Here we offer an exhaustive study of the petrophysical characteristics of the sandstones used in the construction of the Monumental Heritage of Ciudad Rodrigo (Salamanca, Spain).

Five different types of stone were used; namely, the Red, Brown, Striped, Nodular and White, varieties. The differences among these varieties lie in the degree of diagenetic transformation they have undergone. Each of them has important mineralogical, textural and structural differences as compared with its counterparts, implying that each variety will behave differently when used for construction purposes. The Red variety' is the least transformed and hence the least suitable for construction. By' contrast, the White is the variety that has undergone the greatest degree of diagenesis and is hence the most appropriate for such purposes.
PALABRAS CLAVE: Ciudad Rodrigo, areniscas, petrofísica, edificación
KEYWORDS: Ciudad Rodrigo, sandstones, petrophysics, building 


\section{INTRODUCCIÓN}

Ciudad Rodrigo es una urbe fortificada de estilo medieval localizada en el extremo suroccidental de la provincia de Salamanca, y próxima a la frontera con Portugal. A lo largo de los últimos 9 siglos, la piedra arenisca ha sido el material más utilizado en la construcción y sucesivas restauraciones del patrimonio inmobiliario con que cuenta esta ciudad. De forma general, sus características más notables son la compactación y la vistosidad que pueden llegar a presentar. Son areniscas cuya composición química y mincralógica ha sido modificada por los numerosos procesos diagenéticos sufridos y que están rclacionados con la dinámica de las aguas meteóricas, tanto en condiciones freáticas como vadosas (1). Estas transformaciones han influido de forma importante en sus características físicas y mecánicas, modificando su porosidad y mejorando su resistencia y dureza. Estos materiales reciben el nombre de "Areniscas de Ciudad Rodrigo" s.l. (2, 3, 4), y engloban cinco variedades de arenisca diferentes $(1,5)$. La arenisca original es una subarcosa denominada variedad Roja, de la que derivan otras cuatro variedades pétreas: Marrón, Rayada, Nodular y Blanca; cada cual con un grado diferente de transformación diagenética. Las areniscas más transformadas (Rayada, Nodular y Blanca) son también las más demandadas para la construcción. Todas estas variedades pétreas se suceden unas a otras y aparecen bien representadas en la vertical de algunos afloramientos y canteras próximas a la urbe de Ciudad Rodrigo (5) (Fig. 1).

Con el presente trabajo se pretende informar de una serie de propiedades físicas, hídricas, dinámicas y mecánicas que es necesario conocer para poder: a) comprender mejor el estado actual en el que se encuentran estas variedades pétreas, mczcladas entre sí y colocadas en antiguos edificios, y b) facilitar y mejorar su uso tanto en las nuevas edificaciones como en las rehabilitaciones. Tener este conocimiento de los materiales con los que se va a trabajar permitirá saber más sobre: a) sus posibles interacciones con otros elementos completamente ajenos a la piedra, como pueden ser: morteros, revestimientos, tratamientos de conservación, etc. y b) su evolución bajo la acción de determinadas condiciones ambientales y microambientales reinantes en su lugar de ubicación (humedades, contrates térmicos, contaminación atmosférica y/o de las aguas subsuperficiales, actividad orgánica, etc.).

\section{MATERIALES Y MÉTODOS}

Cada tipo de arenisca presenta una mineralogía dominante, lo que condiciona que sus propiedades físicas dificran lo suficiente como para ser la causa principal del comportamiento que muestran estos

\section{INTRODUCTION}

Ciudad Rodrigo is a fortified mediaeval city located in the south-western corner of the province of Salamanca, close to the Portuguese border. Over the past nine centuries, sandstone has been the material most extensively used in the construction of its buildings and the successive restorations of these. Overall, the most salient characteristics of these sandstones are their compactness and their striking aesthetics. The chemical and mineralogical compositions of these stones have been modified by the many diagenetic processes, to which they have been subjected. Such processes are related to the dynamics of meteoric water, both under phreatic and vadose conditions (1). These transformations have affected the physical and mechanical characteristics of the sandstones, altering their porosity and improving their strength and hardness. The sandstones have received the name "Ciudad Rodrigo Sandstones" s.l (2, 3, 4), and encompass five different varieties $(1,5)$. The original stone is subarkosic and is known as the Red variety; all the other types derive from this variety: namely, Brown, Striped, Nodular and White. Each has undergone a different degree of diagenetic transformation. The most transformed varieties (Striped, Nodular and White) are also those most sought for construction purposes. All the varieties follow one another in a vertical succession and are well represented in some outcrops and quarries close to the city (5) (Fig. 1).

The aim of the present work was to address a series of physical, hydric, dynamic and mechanical properties of the different varieties with a view to (a) better understanding their current state, located on ancient buildings; (b) facilitating and improving their use both in new buildings and in restorations. Having this knowledge of the materials with which we are going to work will allow to know more about a) their possible interactions with other elements totally different to the stone, as: mortars, renderings, conservation treatments, etc. and b) their evolution under specific environmental and microenvironmental conditions present in their location place (dampness, thermal contrasts, atmospheric pollution and/or subsurface water contamination, organic activity, etc.).

\section{MATERIALS AND METHODS}

Each variety of sandstone displays a dominant mineralogy, which conditions its physical properties. The differences among these properties are sufficient to be considered as the main cause of the behaviour these 


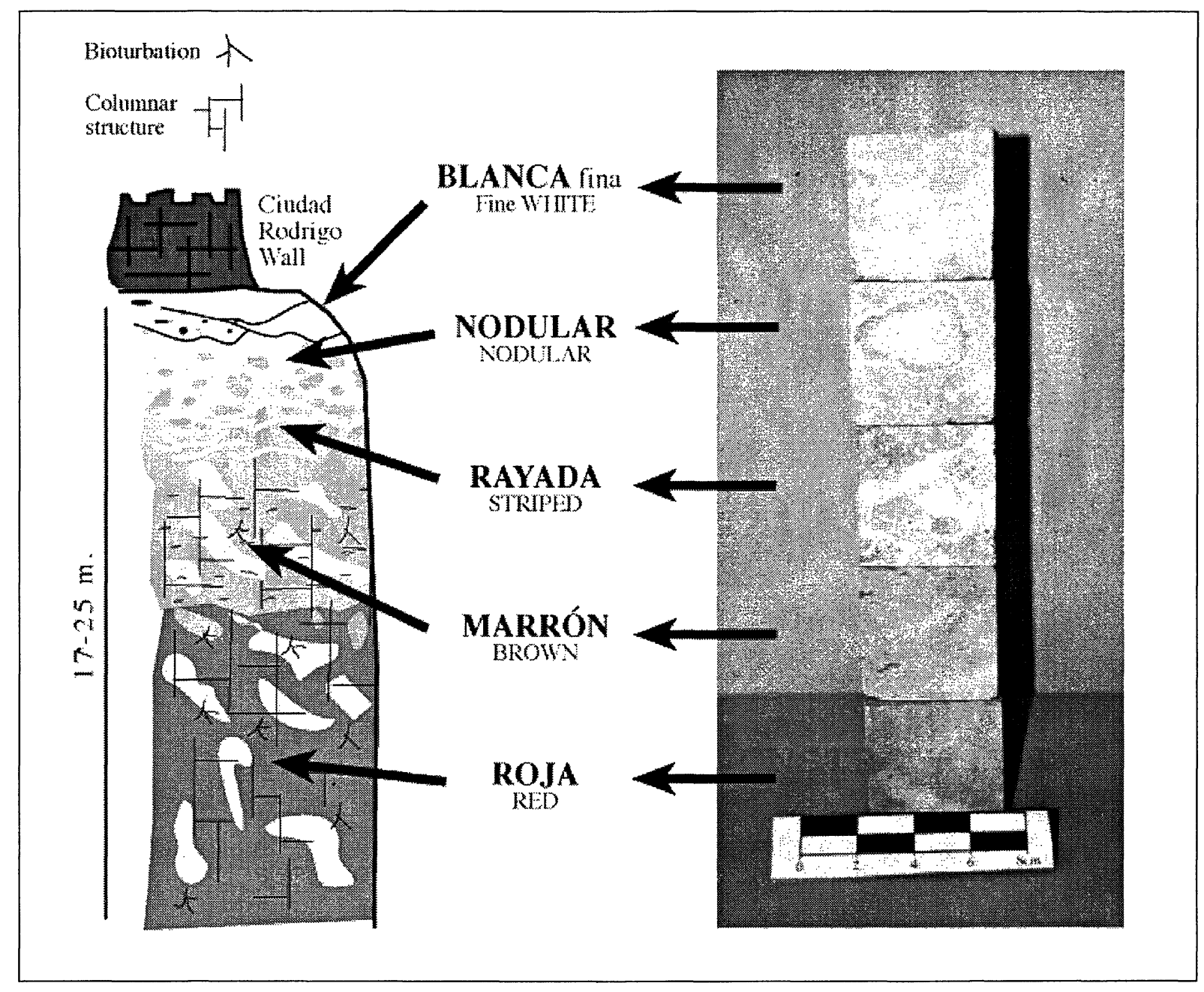

Figura 1.- Identificación de las 5 variedades pétreas en los afloramientos próximos a Ciudad Rodrigo.

Figure 1.- Identification of the five sandstone varieties in the outcrops close to Ciudad Rodrigo.

materiales frente a los diversos agentes de degradación que pueden afectarles una vez colocados en un edificio (5).

1) La variedad Roja es dominante en la zona y aparece en la base de todos los afloramientos estudiados (Fig. 1). Es una arenisca poco o nada transformada, con fuertes contrastes de color (rojo, verdes y ocres), textura rugosa y homogénea, y de escasa consistencia. En realidad, es un fango arenoso de composición silícea que cuenta con un esqueleto heterogéneo y anguloso de clastos de cuarzo, cuarcita, feldespatos,

cloritoesquistos, micaesquistos, etc., incluidos en una matriz arcillosa compucsta por pequeñas micas y teñida por oxihidróxidos de hicrro.

2) La variedad Marrón presenta una textura fina y suave, color marrón claro y gran dureza. En este tipo de arenisca, los silicatos han sido en gran parte reemplazados por una masa microcristalina de materials show when subjected to various decaying agents once they are placed in the construction (5).

1) The Red variety is dominant in the zone and appears at the base of all the outcrops studied (Fig. I). This sandstone has undergone little or no transformation and display strong colour contrasts (red, green and ochre), a rough and homogeneous texture, and is not very consistent. In fact, it is a sandy mud with a siliceous composition supported by a heterogeneous and angular skeleton of clasts: quartzite, feldspars, chloroschists, micaschists, etc., embedded within a clay matrix composed of small micas and stained by iron oxylhydroxides.

2) The Brown variety has a fine-grained smooth texture and is light brown in colour: This variety is very hard; in it, silicates have been largely replaced by a 
naturaleza dolomítica. Presenta pequeñas grietas horizontales de disolución (Fig. 1).

3) La variedad Rayada es una arenisca compactada de grano fino a medio, textura rugosa y heterogénea, y fuerte colorido (tonos rojos, marrones, verdes, ocres). La gran peculiaridad que presentan estas piedras y que las hace muy atractivas para la construcción son las numerosas venas blancas que la recorren en sentido horizontal (Fig. 1). Esta varicdad supone una mezcla entre las dos variedades anteriores. Tiene los silicatos presentes en la variedad Roja y los carbonatos dolomíticos de la variedad Marrón, todo ello atravesado, además, por venas de carbonato calcítico.

4) La variedad Nodular también es un tipo de piedra muy vistosa y utilizada en la edificación. Son fangos arenosos de color gris y textura fina y homogénea, que contienen nódulos de vivos colores (blancos, rojos, rosas o marrones) (Fig. 1). Estos nódulos presentan alta dureza y están formados por una densa masa microcristaliná de carbonato dolomítico, mientras que el resto del material pétreo es un nuevo plasma arcilloso de naturaleza fibrosa, la palygorskita.

5) La variedad Blanca fina es el fango arenoso que aparece coronando los afloramientos, y supone la variedad pétrea más transformada por los procesos diagenéticos acontecidos en la zona. El hecho de que sea ésta la variedad pétrea más superficial y de que posea un cierto grado de dureza, color blanco-gris y textura fina y homogénea, hacen que también sea la más representativa de todas y la más identificada en las construcciones de la ciudad (Fig. 1). En ella, la masa carbonatada (dolomita) domina sobre la arcillosa (palygorskita). Por el contrario, la facies gruesa de esta misma variedad no se utiliza en construcción por ser un conglomerado con arcilla palygorskítica, lo que la hace más blanda, deleznable y poco vistosa.

El estudio petrofísico se realizó a las cinco variedades pétreas anteriormente mencionadas, a pesar de ser las variedades Rayada, Nodular y Blanca fina, las piedras de construcción más empleadas. Se cortaron probetas sanas (sin deterioro físico aparente) de distinto tamaño según la propiedad a medir, aunque por lo general, las dimensiones más utilizadas fueron $50 \times 50 \times 50 \mathrm{~mm}$.

Las propiedades físicas e hídricas que se han determinado son las siguientes:

- Densidad real y aparente en agua (6). La primera es la densidad de la fracción sólida excluyendo sus espacios vacíos, y la segunda, incluyéndolos.

- Permeabilidad al vapor de agua (7). Esta propicdad hídrica permite conocer la transpiración natural de la piedra. dolomitic microcrystalline mass. It displays small horizontal cracks/fissures due to dissolution (Fig. I).

3) The Striped variety is compacted sandstone with a fine-to-medium grain size, a rough and heterogeneous texture, and a striking colouring (red, brown, green and ochre). A marked peculiarity of these stones, which makes them very attractive for use in construction, is the large number of white veins coursing through them in the horizontal direction (Fig. 1). This variety is a mixture of the two previous types. It contains the silicates present in the Red variety and also the dolomitic carbonates of the Brown variety, all crossed by veins of calcium carbonate.

4) The Nodular variety is also a very "elegant" type, much used in construction. It is composed of grey sandy. mud and has a fine and homogeneous texture. This sandy mud features nodules with vivid colours (white, red, pink and brown) (Fig. 1). The nodules are extremely: hard and are formed by a dense microcrystalline mass of dolomitic carbonate. The rest of the material is a new clayey fibrous mass; namely; palygorskite.

5) The White variety is composed of the sandy mud that appears at the top of the outcrops and is the material most transformed by the diagenetic processes affecting the zone. It is the superficial most stone variety and is fairly hard, it has whitish-grey colour, and a fine and homogeneous texture; this means that it is the most representative of all the varieties and the one that can be identified most readily on the buildings of the city (Fig. I). In this variety, the dolomitic mass prevails over the clayey (palygorskite) mass. By contrast, the coarse facies of this variety is not used in construction because it is a conglomerate with clayey mass of palygorskite, meaning that it is soft, crumbly and not very attractive.

The petrophysical study was conducted with all five stone varieties described above even though the Striped, Nodular and White varieties are those most used in construction. Blocks of different sizes (with no apparent physical deterioration) were cut depending on the property to be measured, although in general the dimensions most used were $50 \times 50 \times 50 \mathrm{~cm}$.

The physical and hydric properties studied were as follows:

- Real and apparent density in water (6). The first refers to the density of the solid fraction, excluding void spaces, and the second one refers to density including these.

- Permeability in water vapour (7). This hydric property affords information about the natural transpiration of the stone. 
- Capacidad de imbibición (8). Se define como la cantidad máxima de agua absorbida por el matcrial en condiciones de inmersión total en agua, a presión y temperatura ambiente.

- Coeficiente de absorción capilar (9). El conocimiento de este parámetro hídrico es fundamental en cl estudio de la posible degradación de un material de construcción, ya que los poros y fisuras constituyen los núcleos principales de almacenamiento del agua y las disoluciones. La absorción capilar en los muros de un edificio es una de las fuentes principales de acceso de las disoluciones a la piedra.

- Porosidad de la piedra. Es muy importante conocer su sistema poral (cantidad de poros, tamaño y distribución de los mismos, etc.), ya que regula la dinámica de los fluidos en su interior e incide directamente en los procesos de alteración natural en cantcra y de deterioro en el edificiq. La porosidad se determinó tanto en agua (10) como con el porosímetro de $\mathrm{Hg}$. En cl agua, se obtuvieron datos referentes a la porosidad total accesible al agua, la porosidad libre y el cocficiente de agua absorbida. Con el porosímetro de $\mathrm{Hg}$, además de conocer la porosidad total accesible al $\mathrm{Hg}$ y las densidades real y aparente, también se pudo conocer su distribución porosimétrica en función del tamaño y volumen de poro. El porosímetro de $\mathrm{Hg}$ emplcado fue un QUANTA CHROME compuesto de un AUTOSCAN FILLING APPARATUS 0-24 PSIA, para la distribución de los macroporos, y de un AUTOSCAN-33

POROSIMETER 0-33000 PSIA, para la distribución de los microporos. La microporosidad sc midió en un rango que oscilaba de 7 a $0,006 \mu \mathrm{m}$ de diámetro de poro y la macroporosidad de 7 a $200 \mu \mathrm{m}$. El tamaño de muestra utilizado se corresponde con pequeños iragmentos de aproximadamente $1 \mathrm{~cm}^{3}$.

Propiedades dinámicas determinadas:

- Velocidad de propagación ultrasónica. La velocidad de propagación de las ondas longitudinales (Vp) (11) a través de la piedra en las tres direcciones del espacio depende de su densidad y de sus propiedades elásticas. A su vez, estas últimas están relacionadas con la calidad y resistencia del material pétreo, lo que proporciona una valiosa información acerca de las características petrofísicas y estado del mismo (homogeneidad, poros, fisuras, etc.). El equipo cmpleado fue un ULTRASONIIC TEST BPV, fabricado por STEINKAMP.

Propiedades mecánicas valoradas:

- Resistencia mecánica. Rige el comportamiento de los materiales pétreos bajo esfuerzos mecánicos de diferente tipo (compresión, flexión, tracción,...). La
- Imbibition capacity (8), This is defined as the maximum amount of water absorbed by the stone under conditions of total inmersion at ambient temperature and pressure.

\section{- Capillary absorption coefficient (9). Knowledge of} this parameter is crucial for study of the possible degradation of a stone destined for construction purposes since the pores and microfissures are the points responsible for the storage of water and solutions. Capillary absorption in the walls of a building is one of the main sources of access of solutions to the stone.

- Porosity of the stone. It is important to understand the pore system of a stone (amount of pores, their size and distribution, etc.) since this regulates fluid dynamics inside the material and directly affects the natural weathering processes that occur in quarries and on the outsides of buildings. Porosity was determined both in water (10) and using the $\mathrm{Hg}$ porosimeter. In water, data relating to the total porosity accessible to water, free porosity; and the coefficient of absorbed water were obtained. With the $\mathrm{Hg}$ porosimeter, as well as obtaining information about the total porosity accessible to $\mathrm{Hg}$ and the real and apparent densities, the porosimetric distribution was determined as a function of the size and volume of the pores. The $\mathrm{Hg}$ porosimeter employed was a QUANTA CHROME device, comprising a 0-24 PSIA AUTOSCAN FILLING APPARATUS, for macropore distribution, and a 0-33000 PSIA AUTOSCAN POROSIMETER for micropore distribution. Microporosity was measured in the 7-0.006 $\mu m$ range and macroporosity between 7 and $200 \mu \mathrm{m}$. The fragment size of the samples used was approximately $1 \mathrm{~cm}^{3}$.

\section{Dynamic properties determined:}

- Ultrasound propagation velocity: The propagation velocity of longitudinal waves $(\mathrm{VP})(11)$ through the stone in all three spatial directions depends on the density and elastic properties of the material. The latter are in turn related to the quality and strength of the stone, and provide useful information about the petrophysical characteristics and state of the stone (homogeneity, pores, fissures, etc.). The apparatus employed was an ULTRASONIC TEST BPV made by STEINKAMP.

\section{Mechanical properties assessed:}

- Mechanical strength. This governs the behaviour of stone materials when subjected to different types of mechanical force (compression, flexion, traction, etc.). 
piedra colocada en un edificio puede sufrir daños físicos irreversibles (fisuración,...) cuando se ve sometida a ciertos niveles de tensión. Esto contribuye a acelerar el proceso de deterioro de la piedra y, en conjunto, a provocar la inestabilidad estructural del edificio.

Al carecer la piedra arenisca de una normativa específica a la hora de realizar estos ensayos, se optó por aplicar las normas correspondientes a otras piedras naturales (granito, mármol, etc.), pero con ciertas modificaciones. La presencia de anisotropías estructurales y texturales, fisuración y contenido en agua, se tuvieron en cuenta ya que influían directamente en los valores de resistencia obtenidos. Se cmpleó un equipo hidráulico informatizado de $1.500 \mathrm{kN}$, marca MICROTEST, modelo PEH 1.500-150, $\mathrm{n}^{\circ}$ de seric R150/03. Los ensayos de resistencia mecánica realizados a estas areniscas fucron:

a) Resistencia•a la compresión $(12,13)$. La resistencia a la compresión de un determinado tipo de piedra depende de factores intrínsecos, tales como su mineralogía, textura, porosidad,...y extrínsecos, como: tamaño y forma de las probetas ensayadas, condiciones y tipo de ensayo, ctc. (14). Esta propiedad informa de que cuanto más resistente es una picdra, más durabilidad tiene, aunque existen excepciones. Para la realización de este ensayo se utilizaron probetas cúbicas de 40, 50 y $70 \mathrm{~mm}$ de arista, y el ensayo se realizó tanto en seco como con un grado de saturación en agua del $9 \%$ al $15 \%$.

b) Resistencia a la flexión $(15,16)$. Se emplearon probetas prismáticas de base cuadrada $(40 \times 40 \times 120$ $\mathrm{mm})$. Los ensayos se realizaron tanto en estado seco como húmedo (5-14\%).

c) Resistencia a la Tracción $(17,18)$. Esta propicdad sirve para analizar el comportamiento anisotrópicomecánico en diferentes orientaciones dentro de un mismo bloque pétreo (19). Su conocimiento es importante dado que muchos de los elementos constructivos hechos con piedra, tienen que soportar a menudo más esfuerzos de extensión que de compresión. Para este ensayo se usaron probetas cilíndricas de $100 \mathrm{~mm}$ de diámetro y $50 \mathrm{~mm}$ de altura. El ensayo se realizó en seco y en húmedo (7-8\%).

\section{RESULTADOS Y DISCUSIÓN}

En la Tabla 1 se muestran las propiedades físicas e hídricas de las cinco variedades de arenisca estudiadas. Se diferencian claramente tres grupos, según los valores obtenidos.

A) La variedad Roja, que es la arenisca original de la que derivan las cuatro varicdades restantes, y la variedad Nodular forman el grupo donde los valores de
The stone of buildings may undergo irreversible physical damage (fissuring) when subjected to certain stress levels. This further accelerates the process of deterioration of the stone and overall leads to structural instability of the building.

Since in the case of sandstone there are no specific directives for this type of assay, we decided to apply those corresponding to other natural stones (granites, marble, etc), but with slight modifications. The structural and textural anisotropies, together with the different degrees of fissuring and water contents, were taken into account since these directly affect the strength values contained. A computerised MICROTEST 1.500kN hydraulic device was employed; model 1.500-150, series number R150/03. The mechanical strength tests carried out on the sandstones were as follows:

a) Compression strength $(12,13)$. This depends on intrinsic factors such as its mineralogy, texture, porosity, etc. and also on extrinsic parameters such as the size and shape of the blocks used, the conditions and type of test, etc. (14). This property provides information about how resistant or how hard a stone is. To perform these tests, cubic bocks measuring 30, 50 and $70 \mathrm{~mm}$ in length were used, conducting the tests under both dry conditions and under conditions of 9$15 \%$ water saturation.

b) Flexion strength $(15,16)$. Prismatic blocks with a square base $(40 \times 40 \times 120 \mathrm{~mm})$ were employed. Tests were conducted in both the dry and wet (5-15\%) states.

c) Traction strength $(17,18)$. This property serves to analyse the anisotropic-mechanical behaviour in different orientations within the same block of stone (19). Knowledge of this parameter is important because many construction parts made of stone must often undergo greater extension forces than compression ones. In these tests, cylindrical samples with a diameter of $100 \mathrm{~mm}$ and a height of $50 \mathrm{~mm}$ were used. The tests were performed under both dry and wet (7-8\%) conditions.

\section{RESULTS AND DISCUSSION}

Table I shows the physical and hydric properties of the five varieties of sandstone studied. On the basis of the values obtained, three groups can be clearly differentiated:

A) The Red variety; which is the original sandstone from which all the others derive, and the Nodular variety form the group in which the values of total and 
TABLA 1/TABLE 1

Propiedades físicas e hídricas de las cinco variedades pétreas identificadas como "Areniscas de Ciudad Rodrigo" (5)

(Physical and hydric properties of the five stone varieties identified as "Ciudad Rodrigo Sandstones" (5))

\begin{tabular}{|c|c|c|c|c|c|c|}
\hline & $\underset{R E D}{\operatorname{ROJA}}$ & $\begin{array}{l}\text { MARRÓN } \\
\text { BROWN }\end{array}$ & $\begin{array}{l}\text { RAYADA } \\
\text { STRIPED }\end{array}$ & $\begin{array}{l}\text { NODULAR } \\
\text { NODULAR }\end{array}$ & $\begin{array}{c}\text { BLANCA fina } \\
\text { Fine WHITE }\end{array}$ & \\
\hline $\begin{array}{l}\text { Porosidad Total } \\
\text { Toxal Porrasity }\end{array}$ & 30,38 & 17,22 & 27,70 & 28,92 & 21,74 & $\%$ \\
\hline $\begin{array}{l}\text { Porosidad Libre } \\
\text { Free Porosity }\end{array}$ & 27,27 & 16,06 & 24,46 & 26,92 & 19,97 & $\%$ \\
\hline $\begin{array}{l}\text { Coeficiente de absorción } \\
\text { Cuefficient of atsotption }\end{array}$ & 89,77 & 93,06 & 88,29 & 93,39 & 91,92 & $\%$ \\
\hline $\begin{array}{l}\text { Densidad Real } \\
\text { Real Density }\end{array}$ & 2,64 & 2,72 & 2,68 & 2,66 & 2,72 & $\mathrm{~g} / \mathrm{cm}^{3}$ \\
\hline $\begin{array}{l}\text { Densidad Aparente } \\
\text { Appanent Density }\end{array}$ & 1,84 & 2,25 & 1,94 & 1,89 & 2,13 & $\mathrm{~g} / \mathrm{cm}^{3}$ \\
\hline $\begin{array}{l}\text { Coeficiente de imbibición } \\
\text { por immersión total } \\
\text { coeffecient of imbibition } \\
\text { by total immersion }\end{array}$ & 16,16 & 7,38 & 12.47 & 16,35 & 10,47 & $\%$ \\
\hline $\begin{array}{l}\text { Coeficiente de absorción } \\
\text { capilar - Coefficient of capillary } \\
\text { absonpption }\end{array}$ & $20 \times 10^{-4}$ & $8 \times 10^{-4}$ & $15 \times 10^{-4}$ & $21 \times 10^{-4}$ & $14 \times 10^{-4}$ & $\mathrm{~g} / \mathrm{cm}^{2} \mathrm{~s}^{0,5}$ \\
\hline $\begin{array}{l}\text { Permeabilidad } \\
\text { Permeability }\end{array}$ & $2,8 \times 10^{-4}$ & $2,3 \times 10^{-4}$ & $3,3 \times 10^{-4}$ & $2,6 \times 10^{4}$ & $1.7 \times 10^{-4}$ & $\mathrm{~kg} / \mathrm{cm}^{3} \mathrm{~s}$ \\
\hline
\end{tabular}

porosidad (total y libre), coeficiente de imbibición, coeficiente de absorción capilar y permeabilidad son altos. No sólo son éstas las variedades que más agua absorben sino también las que más rápidamente lo hacen (Fig. 2). La absorción por inmersión total (Fig. 2A) es máxima $(\approx 14-15 \%)$ en las primeras ocho horas de ensayo, mientras que la absorción por capilaridad (Fig. 2B) se ralentiza, tardando hasta dos días en alcanzar sus valores más altos (14-15\%). La alta porosidad y elevado grado de absorción que tienen estos materiales se debe a su alto contenido en arcillas de tipo illita/moscovita (variedad Roja) y palygorskita (variedad Marrón). Esta composición mineralógica también condiciona el coeficiente de agua absorbida como agua libre, que, en general, es menor $(<90 \%)$, salvo en la variedad Nodular donde supone una anomalía, consecuencia del tipo de arcilla dominante. Aparte de rellenarse de agua la porosidad libre cxistente, en esta variedad la palygorskita eleva el coeficiente porque es una arcilla expandible con cierto poder de absorción y retención de moléculas de agua. También, su ligero contenido en carbonato (nódulos) dificulta la movilidad del agua, por lo que su absorción por capilaridad se retarda levemente frente a la variedad Roja (Fig. 2A). En general, la alta porosidad free porosity; the imbibition coefficient, the capillary absorption coefficient and permeability are highest. These varieties not only the ones that absorb the most amount of water, but also do it in the faster way than any of the other varieties (Fig. 2). Absorption by total immersion (Fig. $2 A$ ) was maximum ( $\approx 14-15 \%$ ) during the first eight testing hours whereas absorption due to capillarity (Fig. 2B) slowed down and 2 days were required for maximum values to be reached (14-15\%). The high porosity and elevated degree of absorption shown by these materials are due to its high content in illites/muscovites clay's (Red variety) and palygorskites clays (Brown variety). This mineralogical composition also governs the coefficient of water absorbed as free water, which in general is lower $(<90 \%)$, with the exception of the Nodular variety, due to its dominant type of clay: As well as filling of the free porosity by water, in this variety the palygorskite raises the coefficient because it is swellable clay with a certain capacity to absorb and retain water molecules. Also, its low content in carbonate (nodules) hinders water mobility; such that its absorption due to capillarity is slightly delayed with respect to the Red variety (Fig. 2A). In general, the high porosity shown by this 

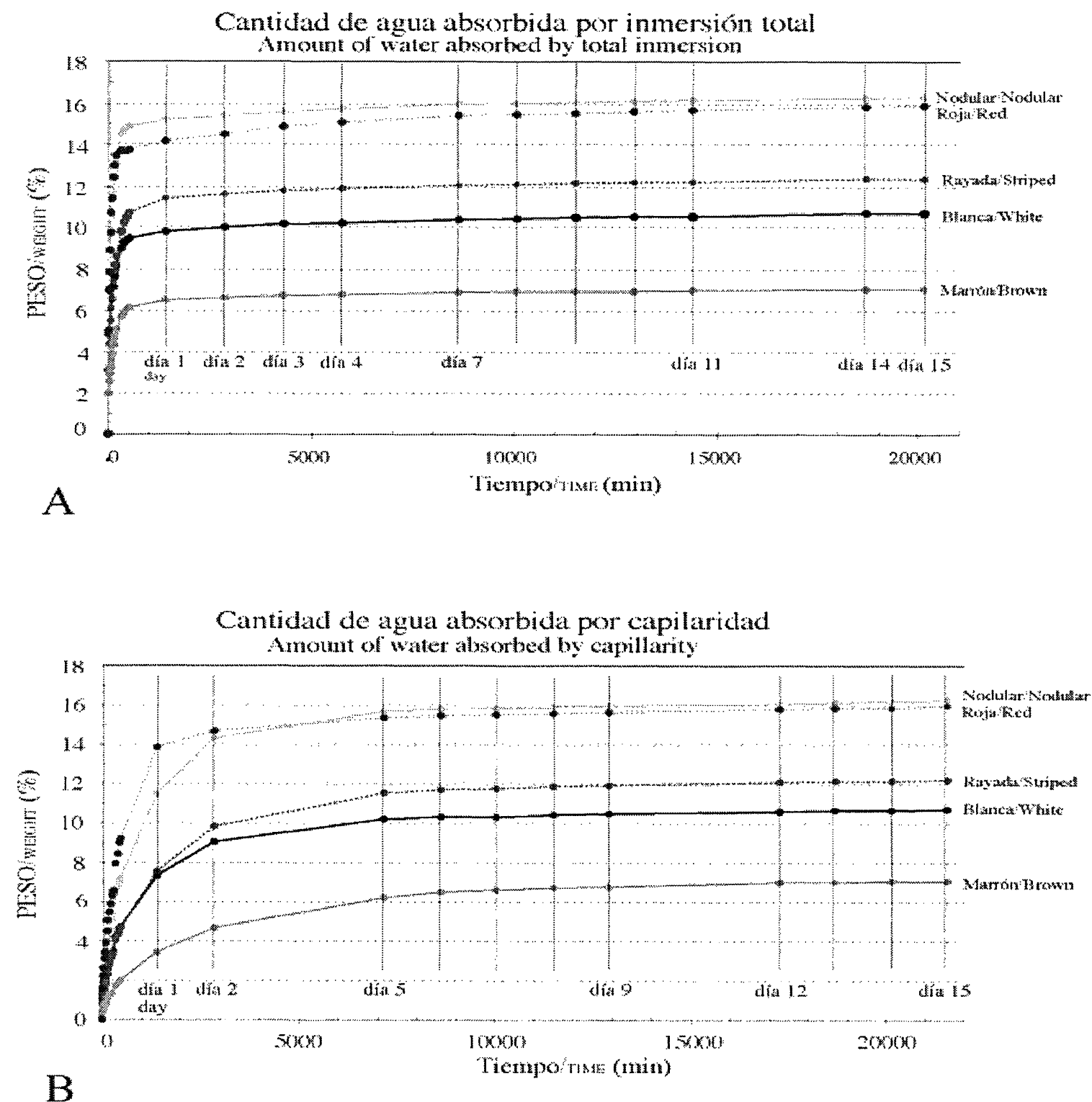

Figura 2.- Gráficas que representan la capacidad de absorción de las diferentes variedades de arenisca analizadas. Figure 2.- Plots showing the absorption capacities of the different sandstone varieties analysed.

que posce este grupo incide en una menor densidad real y aparente y en una mayor diferenciación entre ambas.

B) Las variedades Marrón y Blanca suponen el grupo opuesto al anterior. Presentan menor porosidad (total y libre), coeficiente de imbibición, coeficiente de absorción capilar y permeabilidad. Ambas variedades group leads to lower real and apparent densities and a greater differentiation between both.

B) The Brown and White varieties diverge from the previous group. They have lower total and free porosity; a lower imbibition coefficient, a lower capillary absorption coefficient, and a lower 
no son sólo las que menos agua absorben sino también las que más lentamente lo hacen (Fig. 2). Como en el caso del grupo anterior, la absorción por inmersión es casi total $(6,5 \%$ y $9,5 \%)$ en las primeras ocho horas de ensayo (Fig. 2A). Por el contrario, la absorción capilar (Fig. 2B) es más retardada, tardando hasta cinco y seis días en alcanzar los valores máximos $(6,5 \%$ y $10,25 \%)$. La capilaridad en la variedad Marrón no sólo es más baja que en la Blanca sino también más lenta. Todo esto se debe a que el carbonato dolomítico compone mayoritariamente ambas variedades, y rellena gran parte de la porosidad y microporosidad original, lo que provoca un descenso en el número de espacios vacíos existentes, y en consecuencia, un aumento en sus densidades real y aparente. Al ser pequeña la diferencia entre porosidad total y libre, y alto el coeficiente de agua absorbida como agua libre (92-93\%), las dos variedades absorben casi la totalidad del agua bajo condiciones atmosféricas normales. La presencia cn la variedad Blanca de cantidades significativas de arcilla (palygorskita) hace que los valores de porosidad, densidad y absorción de agua sean algo más altos que en la varicdad Marrón. Por el contrario, la variedad Marrón es más permeable que la Blanca y a cllo influye la presencia de pequeñas y finas grietas de disolución donde puede llegar a condensarse cl vapor de agua atmosférico.

C) El grupo intermedio está representado por la variedad Rayada. Su alta heterogeneidad composicional (arcillas y carbonatos) explica sus propiedades petrofísicas. Los valores de porosidad, coeficiente de agua absorbida como agua libre y densidad se asimilan a los del primer grupo (A) de areniscas más arcillosas, y principalmente, a la variedad Nodular. Por el contrario, los valores de absorción por inmersión y capilaridad (Fig. 2) son más parecidos a los del segundo grupo (B) de areniscas carbonatadas y, más concretamente, a la variedad Blanca. La variedad Rayada se caracteriza por tener un fuerte entramado de venas horizontales de carbonato que conservan su orientación una vez colocada la variedad en un edificio. Suponemos que las venas carbonatadas, más impermeables que el resto de los componentes, actúan de barrera obstaculizando el desplazamiento vertical del agua (menor capilaridad), pero favoreciendo su desplazamiento horizontal (mayor permeabilidad) al aprovechar las superficies de separación (discontinuidades) entre las diferentes fases mineralógicas.

La Tabla 2 refleja los datos de porosidad total y densidad (real y aparente) obtenidos tanto en agua como con el porosímetro de $\mathrm{Hg}$. Los resultados son muy similares y, por tanto, fiables. La salvedad la marca la variedad Rayada, cuyas anisotropías estructurales y texturales suponen un problema a la hora de utilizar el porosímetro de $\mathrm{Hg}$ debido a que la escasa muestra que permeability: Both varieties are not only the ones that absorb the least amount of water, but also the ones that do it in the slowest way (Fig. 2). As in the case of the previous group, absorption by immersion is almost total $(6.5 \%$ and $9.5 \%)$ in the first 8 testing hours (Fig. 2A). By contrast, capillary absorption (Fig. 2B) is more delayed, and takes up to 5-6 days for maximum values to be reached (6.5\% and 10.25\%). In the Brown variety; capillarity is not only lower than in the White variety but also slower. All this is due to the fact that the dolomitic carbonate is the main component in both varieties and fills a large part of the original porosity. and microporosity; leading to a decrease in the number of void spaces and, as a result, an increase in the real and apparent densities. Since the difference between total and free porosity is small and since the coefficient of water absorbed in free form (92-93\%) is high, both varieties absorb almost all the water under normal atmospheric conditions. The presence in the White variety of significant amounts of clay (palygorskite) means that the porosity, density, and water absorption values are slightly higher than in the Brown variety: By contrast, the Brown variety is more permeable than the White variety; due to the presence of small and thin dissolution cracks/fissures, in which atmospheric water vapour may condense.

C) The intermediate group is represented by the Striped variety: Its high compositional heterogeneity (clays and carbonates) accounts for its petrophysical

characteristics. The values of porosity; the coefficient of water absorbed in free form, and density are similar to those of the first group (A) of more clayey sandstones, mainly the Nodular variety: By contrast, the values of absorption by immersion and capillarity (Fig. 2) are more similar to those found for the second group $(B)$ of carbonate sandstones, in particular the White variety. The Striped variety features a visible lattice of horizontal carbonate veins that conserve their orientation once on the walls of buildings. We assume that such veins, which are more impermeable than the rest of the components, act as a barrier, hindering the vertical displacement of water (lower capillarity), but favouring its horizontal displacement (higher capillarity) since the water takes advantage of separation surfaces (discontinuities) between the different mineralogical phases.

Table 2 show's the data on total porosity and density (real and apparent) obtained both in water and with the $\mathrm{Hg}$ porosimeter: The results are very similar and hence reliable. The only exception is the Striped variety; whose structural and textural anisotropies are a problem when using the $\mathrm{Hg}$ porosimeter due to the fact that the small sample employed is not a representative 
TABLA 2/TABLE 2

Comparación entre diversas propiedades físicas obtenidas, tanto en agua como con el porosímetro de mercurio.

(Comparison among different physical properties obtained both in water and by the Hg porosimeter)

\begin{tabular}{|c|c|c|c|c|c|c|}
\hline \multirow{3}{*}{$\begin{array}{l}\text { Variedades } \\
\text { pétreas } \\
\text { Stone } \\
\text { varieties } \\
\end{array}$} & \multicolumn{3}{|c|}{$\begin{array}{l}\text { PROPIEDADES FÍSICAS } \\
\text { en agua } \\
\text { Physical properties in water }\end{array}$} & \multicolumn{3}{|c|}{$\begin{array}{l}\text { PROPIEDADES FÍSICAS } \\
\text { en mercurio } \\
\text { Physical properties in } \mathrm{Hg}\end{array}$} \\
\hline & \multirow{2}{*}{$\begin{array}{l}\text { Porosidad } \\
\text { Total }(\mathrm{t} \%) \\
\text { Total porosity }\end{array}$} & \multicolumn{2}{|c|}{$\begin{array}{c}\text { Densidad/density } \\
\left(\mathrm{g} / \mathrm{cm}^{3}\right)\end{array}$} & \multirow{2}{*}{$\begin{array}{l}\text { Porosidad } \\
\text { Total }(\mathrm{t} \%) \\
\text { Total porosity }\end{array}$} & \multicolumn{2}{|c|}{$\begin{array}{c}\text { Densidad/density } \\
\left(\mathrm{g} / \mathrm{cm}^{3}\right)\end{array}$} \\
\hline & & $\begin{array}{l}\text { Real } \\
\text { Real }\end{array}$ & $\begin{array}{c}\text { Aparente } \\
\text { Apparent }\end{array}$ & & $\begin{array}{l}\text { Real } \\
\text { Real }\end{array}$ & $\begin{array}{l}\text { Aparente } \\
\text { Apparent }\end{array}$ \\
\hline $\begin{array}{l}\text { Blanca } \\
\text { White }\end{array}$ & 21,74 & 2,72 & 2,13 & 21,48 & 2,62 & 2,08 \\
\hline $\begin{array}{l}\text { Nodular } \\
\text { Nodular }\end{array}$ & 28,92 & 2,66 & 1,89 & 28,94 & 2,43 & 1,76 \\
\hline $\begin{array}{l}\text { Rayada } \\
\text { Striped }\end{array}$ & 27,70 & 2,68 & 1,94 & 19,21 & 2,49 & 2,04 \\
\hline $\begin{array}{l}\text { Marrón } \\
\text { Brown }\end{array}$ & 17,22 & 2,72 & 2,25 & 15,10 & 2,75 & 2,35 \\
\hline $\begin{array}{l}\text { Roja } \\
\text { Red }\end{array}$ & 30,38 & 2,64 & 1,84 & 29,20 & 2,55 & 1,84 \\
\hline
\end{tabular}

se emplea no es un marcador representativo del conjunto pétreo. Por ello se pueden aceptar los valores obtenidos en agua, bastante fiables para las otras cuatro variedades pétreas, y donde las dimensiones de las probetas ensayadas son más representativas $(50 \times 50 \times 50 \mathrm{~mm})$.

La Tabla 3 y la Figura 3 muestran la microporosidad que posee cada una de las cinco variedades pétreas ensayadas y su distribución interna. En todas ellas, la microporosidad $(7-0,006 \mu \mathrm{m})$ supone más del $90 \%$ de la porosidad total que poseen, concentrándose principalmente entre 0,5 y $0,01 \mu \mathrm{m}$ de diámetro de poro, y más concretamente $(>50 \%)$ por debajo de $0,2 \mu \mathrm{m}$ de diámetro. La variedad Roja presenta microporos de gran tamaño y una clara distribución bimodal (Tabla 3; Fig. 3a). Esta microporosidad va a evolucionar a medida que se transforma en las otras cuatro variedades. Aunque no supone una modificación sustancial de la misma, sí se aprecia la desaparición en un primer momento de la microporosidad heredada de mayor tamaño de poro (1,5-0,4 $\mu \mathrm{m}$ de diámetro).

La siguiente variedad pétrea que la sucede (variedad Marrón) sigue teniendo ciertas similitudes con la anterior en cuanto al tamaño medio de poro (Tabla.3; Fig. 3b), pero su volumen medio y la superficie marker of the whole stone. Accordingly, it is necessary to accept the values obtained in water, which are fairly reliable for the other four stone varieties and for which the dimensions of the block samples used are more representative $(50 \times 50 \times 50 \mathrm{~cm})$.

Table 3 and Figure 3 show the microporosity of each of the five stone varieties assayed and its internal distribution. In all varieties, microporosity (7-0.006 $\mu \mathrm{m})$ accounts for more than $90 \%$ of the total porosity of the stone types and is mainly concentrated in the 0.5-0.01 $\mu \mathrm{m}$ pore diameter range. More particularly (>50\%) below a pore diameter of $0.2 \mu \mathrm{m}$. The Red variety has large micropores and a clear bimodal distribution (Table 3, Fig. 3a). This microporosity evolves as this variety is transformed into the other four varieties. Although this does not involve a substantial modification, it is possible to note the disappearance of the larger pore-size inherited microporosity (1.5-0.4 um diameter) of the first stage of evolution

The Brown variety shows certain similarities with this latter as regards mean pore size (Table 3, Fig. 3b), but its mean volume and specific pore surface area are considerably reduced, indicating that such pores are 
TABLA 3/TABLE 3

Datos de microporosidad óbtenidos con el porosímetro de mercurio (Microporosity data obtained with the $\mathrm{Hg}$ porosimeter)

\begin{tabular}{|c|c|c|c|c|c|}
\hline \multicolumn{5}{|c|}{ POROSIMETRÍA DE MERCURIO/Hg POROSIMETER } \\
\hline $\begin{array}{c}\text { Variedades } \\
\text { pétreas } \\
\text { Stone } \\
\text { varieties }\end{array}$ & $\begin{array}{c}\text { Microporosidad } \\
\text { entre 7-0.006mm } \\
\text { de diámetro } \\
(\mathrm{t} \%)\end{array}$ & $\begin{array}{c}\text { Tamaño } \\
\text { dominante } \\
\text { de poro } \\
(\mathrm{mm})\end{array}$ & $\begin{array}{c}\text { Tamaño } \\
\text { medio } \\
\text { de poro } \\
(\mathrm{mm})\end{array}$ & $\begin{array}{c}\text { Volumen } \\
\text { medio } \\
\text { de poro } \\
(\mathrm{cc} / \mathrm{g})\end{array}$ & $\begin{array}{c}\text { Superficje } \\
\text { específica } \\
\left(\mathrm{m}^{2} / \mathrm{g}\right)\end{array}$ \\
\hline $\begin{array}{l}\text { Blanca } \\
\text { White }\end{array}$ & 94,30 & $<0.086$ & 0,0357 & 0,070 & 1,94 \\
$\begin{array}{l}\text { Nodular } \\
\text { Nodular } \\
\text { Rayada } \\
\text { Striped } \\
\text { Marrón }\end{array}$ & 94,44 & $<0,064$ & 0,0294 & 0,108 & 4,04 \\
$\begin{array}{l}\text { Brown } \\
\text { Roja } \\
\text { Red }\end{array}$ & 93,35 & $<0,043$ & 0,0268 & 0,060 & 3,36 \\
\hline
\end{tabular}
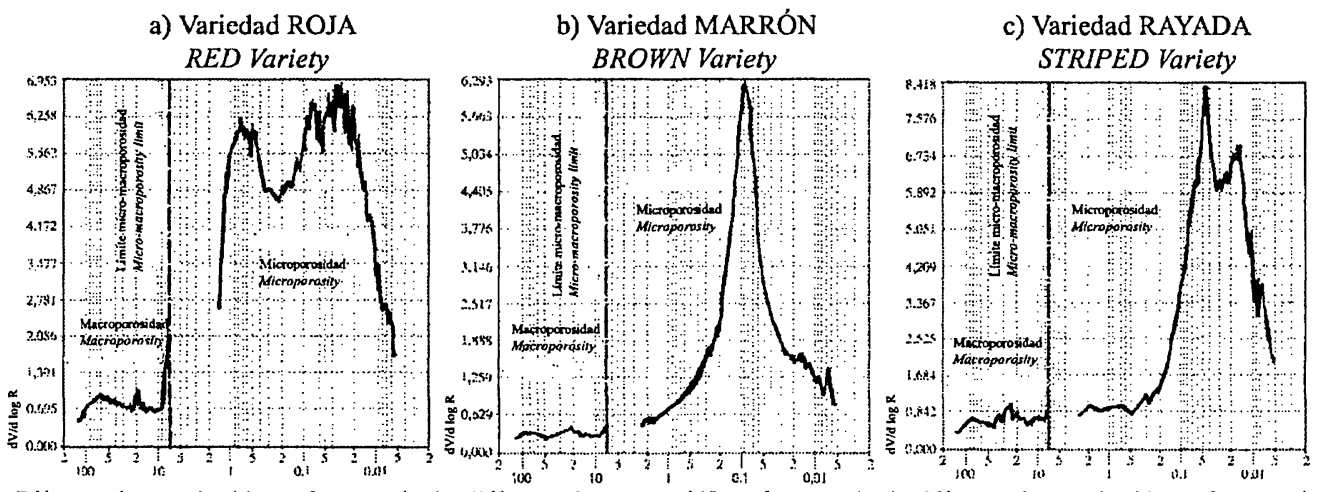

Diámetro de poro $(\mu \mathrm{m}) /$ Pore diameter $(\mu \mathrm{m})$ Diámetro de poro $(\mu \mathrm{m}) /$ Pore diameter $(\mu \mathrm{m})$ Diámetro de poro $(\mu \mathrm{m}) /$ Pore diameter $(\mu \mathrm{m})$

d) Variedad NODULAR NODULAR Variety

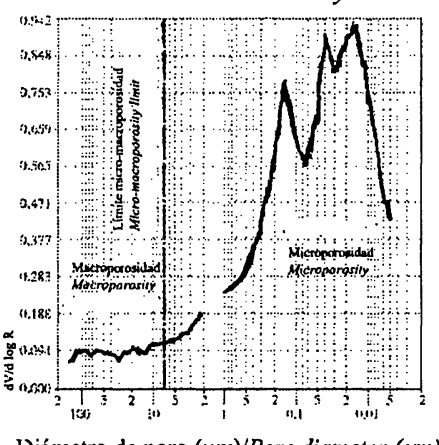

Diámetro de poro $(\mu \mathrm{m}) /$ Pore diameter $(\mu \mathrm{m})$ e) Variedad BLANCA WHITE Variety

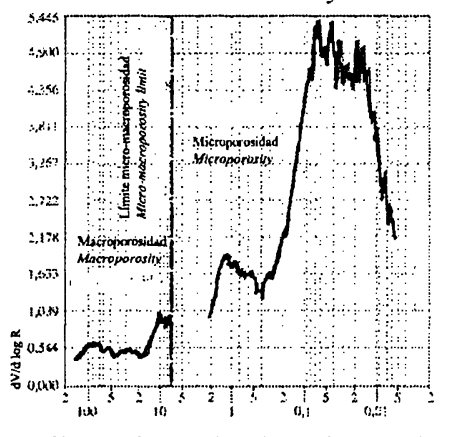

Diámetro de poro $(\mu \mathrm{m}) /$ Pore diameter $(\mu \mathrm{m})$

Figura 3.- Distribución de la microporosidad existente en cada una de las cinco variedades pétreas estudiadas. Figure 3.- Plots showing the distribution of microporosity in each of the five stone varieties studied. 
específica del mismo se reducen considerablemente, indicando que estos poros son más regulares.

Asimismo, su distribución es muy selectiva, en torno a $0,1 \mu \mathrm{m}$ de diámetro, algo que no se ha observado en las otras variedades.

Las otras tres variedades pétreas (Tabla 3.; Fig. 3c, d, e) con mayor grado de transformación presentan tamaños de poro muy pequeños ( $<0,1 \mu \mathrm{m}$ de diámetro). En el caso de la variedad Nodular, los microporos cuentan además con una superficie específica y un volumen medio grandes (Tabla 3), lo que indica morfologías de poro muy irregulares consecuencia de la mineralogía fibrosa (palygorskita) dominante en esta variedad. Los valores de la variedad Rayada pueden ser orientativos de su composición más carbonatada, ya que la distribución de su microporosidad (Fig. 3c) y los datos de porosidad total (Tabla 2) se relacionan más con este tipo de mineralogía.

Los trabajos experimentales sobre microsistemas de alteración en condiciones naturales indican que para tamaños de diámetro de poro $<1 \mu \mathrm{m}$ la dinámica de las soluciones en su interior es muy lenta $(20,21,22)$. Extrapolar al campo de la construcción este concepto de movilidad de las soluciones en un material pétreo según cl tamaño de poro dominante en el mismo, no es en ningún momento erróneo ya que el contexto dinámico en ambos campos sigue las mismas leyes físicas. El hecho de que más del 50\% de la microporosidad de estas areniscas posea un tamaño de poro $<0,2 \mu \mathrm{m}$ de diámetro supone un factor negativo a la hora de considerar el grado de deterioro físico y químico que pueden llegar a sufrir estas piedras una vez colocadas en un edificio, ya que un contacto prolongado de las soluciones con la mineralogía de las piedras facilita la acción mecánica y química de agentes tan degradantes como el agua y las sales.

La microporosidad dominante en la arenisca original Roja ( $<0,2 \mu \mathrm{m})$ dificulta la movilidad de las soluciones acuosas que la impregnan, acentuándose más en las restantes variedades que derivan de su transformación (Marrón, Rayada, Nodular y Blanca) y donde su microporosidad evoluciona a tamaños dominantes aún menores $(<0,1 \mu \mathrm{m}$ de diámetro de poro). La presencia permanente de soluciones rellenando la microporosidad de las variedades Rayada, Nodular y Blanca, llega a provocar una disgregación parcial de la superficie de estas piedras puestas en una obra.

La Tabla 4 analiza la velocidad de propagación de las ondas ultrasónicas en las tres direcciones del espacio. La variedad original (Roja) presenta los valores de propagación (V1, V2 y V3) más bajos. Su valor medio ronda $\operatorname{los} 1.900 \mathrm{~m} / \mathrm{s}$, lo que indica una escasa anisotropía estructural y textural, y es coincidente con more regular. Also, their distribution is very selective (around $0.1 \mu \mathrm{m}$ diameter), which is not seen for the other varieties.

The other three stone varieties (Table 3, Fig. 3c, d, e), with a greater degree of transformation, show very small pore sizes $(<0.1 \mu m$ diameter). In the case of the Nodular variety; the micropores also have a large specific surface area and mean volume (Table 3), indicating very irregular pore morphologies as a result of the fibrous mineralogy (palygorskite) dominant in this variety: The values found for the Striped variety can be considered orientative of its more carbonated composition since the distribution of its microporosity (Fig. 3c) and the data of total porosity (Table 2) are more related to this type of mineralogy.

Previous experiments on the alteration microsystems under natural conditions have shown that for pore diameters of $<1 \mu \mathrm{m}$ the solutions dynamic inside is very slow $(20,21,22)$. Bearing in mind the concept of solutions mobility inside stone materials according to the dominant pore size, this is important in the construction industry. The fact that more than 50\% of the microporosity of these sandstones has a pore size of less than $0.2 \mu \mathrm{m}$ in diameter is a negative factor when considering the degree of physical and chemical deterioration that such stones may undergo when used in buildings. Since prolonged contact between the solutions and the mineralogy of the stone facilitates the mechanical and chemical action of decaying agents, such as water and salts.

The dominant microporosity of the original Red variety $(<0.2 \mu \mathrm{m})$ hinders the mobility of the aqueous solutions impregnating it, and this is further exacerbated in the derived varieties in which the microporosity evolves to an even smaller dominant sizes $(<0.1 \mu$ m pore diameter). The permanent presence of solutions filling the microporosity of the Striped, Nodular and White varieties even elicits a partial breakdown of their surface when such stones are used in construction.

Table 4 analyses the velocity of propagation of ultrasound waves in the three spatial directions. The original variety (Red) shows lower propagation velocities (V1, V2 and V3). The mean value is about $1900 \mathrm{~m} / \mathrm{s}$, indicating that there is little structural and textural anisotropy, and this value coincides with the 
Velocidad de propagación de los ultrasonidos en estas areniscas

(Ultrasound propagation velocity in the sandstones studied)

\begin{tabular}{|c|c|c|c|c|c|c|c|c|c|c|c|c|c|c|c|c|}
\hline \multirow{2}{*}{\multicolumn{2}{|c|}{$\begin{array}{l}\text { Variedades/Varieties } \\
\text { Muestras/Samples }\end{array}$}} & \multicolumn{3}{|c|}{ Roja / Rèd } & \multicolumn{3}{|c|}{ Marrón / Brown } & \multicolumn{3}{|c|}{ Rayada / Striped } & \multicolumn{3}{|c|}{ Nodular/Nodular } & \multicolumn{3}{|c|}{ Blanca / white } \\
\hline & & $r$ & $\mathrm{~V} 2$ & V3 & $\mathrm{V}_{1}$ & V2 & V3 & V1 & $\mathrm{V} 2$ & $\sqrt{3}$ & $\mathrm{V1}$ & $\sqrt{2}$ & V3 & $\mathrm{V1}$ & V2 & $\sqrt{3}$ \\
\hline \multirow{4}{*}{$\begin{array}{l}\text { Valores puntuales } \\
4 \text { probetas } \\
\text { Puntual values } \\
4 \text { samples }\end{array}$} & 1 & & & 42 & & & & & 2146 & & & 2008 & & 678 & 2934 & \\
\hline & 2 & & & & & & & & & & & & & & & \\
\hline & 3 & & & & & & & & & & & & & & & \\
\hline & 4 & & & & & & & & & & & & & & 2784 & \\
\hline \multicolumn{2}{|c|}{$\begin{array}{l}\text { Valor medio } 8 \text { probetas } \\
\text { Mean value } 8 \text { samples }\end{array}$} & & 924 & 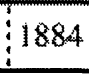 & & & & & & & & & & 2609 & 277 & \\
\hline
\end{tabular}

la baja densidad y alta porosidad de su mineralogía silícea. En la variedad Marrón, los valores de propagación se disparan hasta $2.600-2.800 \mathrm{~m} / \mathrm{s}$ debido a que son materiales muy densos y poco porosos (presencia de carbonatos). La escasa anisotropía que presentan se debe a la existencia de pequeñas grietas longitudinales de disolución que reducen la velocidad $\mathrm{V} 3$ cuando son atravesadas perpendicularmente. La variedad Rayada baja ligeramente a 2.400-2.600 m/s, dando diferentes valores según la dirección de transmisión de las ondas. Las velocidades V1 y V2 son similares porque la propagación se realiza paralelamente a las venas carbonatadas que presenta esta variedad. Por el contrario, la velocidad V3 difiere de las anteriores porque se lleva a cabo transversalmente a las venas, y estas ondas tienen que atravesar distintas fases mineralógicas de densidad y porosidad variadas. En la variedad Nodular, estos valores siguen cayendo hasta $2.100-2.300 \mathrm{~m} / \mathrm{s}$ de velocidad media, e incluso puntualmente llegan a bajar de $\operatorname{los} 1.700 \mathrm{~m} / \mathrm{s}$. Esto es debido al amplio dominio que tienen las arcillas palygorskíticas, porosas y de menor densidad. La dispersión de las tres velocidades de propagación muestra la existencia de una fuerte anisotropía estructural consecuencia de los nódulos carbonatados que posee esta variedad de forma dispersa. La variedad Blanca refleja una nueva subida de las velocidades, volviendo a alcanzar los $2.600-2.800 \mathrm{~m} / \mathrm{s}$ de velocidad media. Esto es debido a su fuerte contenido en carbonatos, los cuales hacen bajar la porosidad y subir la densidad del material pétreo. Pero la presencia también de arcillas palygorskíticas en esta variedad se manifiesta por la existencia de una dispersión clara de las velocidades de propagación en las tres direcciones del espacio. En definitiva, por los datos obtenidos, estas areniscas quedan englobadas en el gran grupo de las Rocas Cementadas (1.400-6.000 m/s), y más concretamente entre el grupo de las Areniscas (1.400-4.000 m/s) y el de las Calizas $(2.500-6.000 \mathrm{~m} / \mathrm{s})(23,24)$. low density and high porosity of the siliceous mineralogy of the stone. In the Brown variety, the propagation values increase sharply' to $2.600-2.800 \mathrm{~m} / \mathrm{s}$ because these materials are very dense and not very porous (presence of carbonates). The small degree of anisotropy observed is due to the existence of small longitudinal fissures due to dissolution, which reduce the V3 velocity when they are crossed perpendicularly. In the Striped variety it decreases slightly to $2.400-2.600 \mathrm{~m} / \mathrm{s}$, different values being observed depending on the direction of transmission of the waves. The V1 and V2 velocities are similar because in this case propagation is carried out parallel to the carbonated veins of this variety. By contrast, the $V 3$ velocity is different from the other velocities because it occurs transversally to the veins and these waves must travel across different mineralogical phases of varying density and porosity. In the Nodular variety, these values continue to decrease down to a velocity of $2.100-2.300 \mathrm{~m} / \mathrm{s}$ and may even descend as low as $1.700 \mathrm{~m} / \mathrm{s}$. This is due to the strong dominance of palygorskite clays, which are porous and with lower density. The dispersion of the three propagation velocities points to the existence of a strong structural anisotropy, a consequence of the carbonated nodules dispersed throughout this variety. The White variety shows a new increase in velocities, a mean value of $2.600-2.800 \mathrm{~m} / \mathrm{s}$ being attained. This is due to its strong carbonate content, which elicits a decrease in porosity and an increase in the density of the material. However, the presence too of palygorskite in this variety is manifested by the existence of a clear dispersion in the propagation velocities in all three spatial directions. In sum, according to the data obtained these sandstones can be included within the large Cemented Rock group $(1.400-6.000 \mathrm{~m} / \mathrm{s})$, and, more specifically; between the Sandstone group $(1.400-4.000 \mathrm{~m} / \mathrm{s})$ and the Limestone group $(2.500-6.000 \mathrm{~m} / \mathrm{s})(23,24)$. 
La Tabla 5 muestra las propiedades mecánicas que poseen estas cinco areniscas. En general, al ser materiales porosos, no se necesita aplicar mucha fuerza de carga para que rompan (300-70 N/s). Su resistencia a la rotura depende: a) de su mineralogía dominante, ya que controla la porosidad de la piedra y con ella el grado de saturación en agua, y b) de sus posibles anisotropías estructurales y texturales, ya que la resistencia mecánica varía scgún que los esfuerzos actúen en una dirección u otra (perpendicular o paralclamente a la estratificación y/o fisuración natural).

Las cuatro variedades pétreas que derivan de la variedad Roja original por transformación diagenética, denotan un notable aumento de su resistencia a la compresión, tanto en estado seco como húmedo. En este tipo de resistencia mecánica parece no influir la presencia de venas (variedad Rayada) y grictas (variedad Marrón), pero sí cl tamaño de las probetas. La determinación de la resistencia a la flexión da problemas por las dimensiones de las probetas, pero sí se puede destacar que la presencia de venas y grietas en las picdras influye en su resistencia a la rotura, disminuyendo en el caso de que los esfuerzos sean aplicados paralelamente a estas estructuras. La resistencia a la tracción presenta los mismos matices que la resistencia a la compresión. Ésta aumenta en las variedades pétreas que derivan de la variedad original (Roja) y no influyc la presencia de venas y grietas. La resistencia a la tracción y a la flexión en estado húmedo
Table 5 shows the mechanical properties of the five sandstones studied. Overall, since they are porous materials little load force is required for them to break (300-70 N/s). Their shearing strength depends on (a) their dominant mineralogy, since this controls the porosity of the stone and with it the degree of saturation in water and $(b)$ their possible structural and textural anisotropies, since mechanical strength varies according to the forces acting in one direction or another.

The four stone varieties deriving from the Red variety due to diagenetic transformation show a notable increase in compression strength both in the dry and in the wet state. In this type of mechanical strength, the presence of veins (Striped variety) and cracks/fissures (Brown variety) seems to have no bearing, although the size of the block samples does. Determination of the flexion strength is hindered by problems deriving from the size of the samples, although it can be seen that the presence of veins and cracks in the stones affects their strength to breakage, this decreasing when the forces are applied parallel to such structures. The traction strength follows the same trends as compression strength. This latter strength increases in the stone varieties deriving directly from the Red variety and the presence of veins and cracks/fissures does not affect it. The traction and flexion strengths in the wet state had to be discarded since most block samples were unable

TABLA 5/TABLE 5

Propiedades mecánicas de las cinco variedades de arenisca identificadas en Ciudad Rodrigo (Mechanical properties of the five sandstone varieties identified in Ciudad Rodrigo)

\begin{tabular}{|c|c|c|c|c|c|c|c|c|c|c|c|}
\hline \multirow{3}{*}{$\begin{array}{l}\text { Variedades } \\
\text { pétreas } \\
\text { Stone } \\
\text { varieties }\end{array}$} & \multicolumn{3}{|c|}{$\begin{array}{cc}\text { Resistencia } & \text { Conpression } \\
\text { a la compresión } & \text { strength }\end{array}$} & \multicolumn{3}{|c|}{$\begin{array}{l}\text { Resistencia } \\
\text { a la flexión }\end{array}$} & $\begin{array}{l}\text { Aexion } \\
\text { strenght }\end{array}$ & \multicolumn{3}{|c|}{$\begin{array}{c}\text { Resistencia } \\
\text { a la tracción }\end{array}$} & $\begin{array}{l}\text { Traction } \\
\text { strength }\end{array}$ \\
\hline & \multicolumn{2}{|c|}{ Secoldy } & Húmedowet & \multicolumn{2}{|c|}{ Secoidry } & \multicolumn{2}{|c|}{ Húmedoisct } & \multicolumn{2}{|c|}{ Secoipry } & \multicolumn{2}{|c|}{ Húmedo:wet } \\
\hline & $\begin{array}{l}\text { Mediałkas } \\
\text { (Mpa) }\end{array}$ & $\begin{array}{c}\text { Velocidad } \\
\text { rotura (Nis) } \\
\text { Breaking viocity } \\
\end{array}$ & 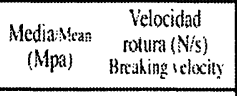 & $\begin{array}{c}\text { Media:Men } \\
\text { (Mpa) }\end{array}$ & \begin{tabular}{c|}
$\begin{array}{c}\text { Velocidad } \\
\text { roturn (N/s) } \\
\text { Breuking velocits }\end{array}$ \\
\end{tabular} & $\begin{array}{l}\text { Mediankan } \\
\text { (Mpa) }\end{array}$ & $\begin{array}{c}\text { Velocidad } \\
\text { mfura (Nis) } \\
\text { Breaking vel(xity } \\
\end{array}$ & $\begin{array}{c}\text { Mediakilem } \\
\text { (Mpa) }\end{array}$ & $\begin{array}{c}\text { Velocidad } \\
\text { rotura (Nis) } \\
\text { Breaking velocity }\end{array}$ & $\begin{array}{c}\begin{array}{c}\text { Media:Atean } \\
\text { (Mpa) }\end{array} \\
\end{array}$ & $\begin{array}{c}\text { Velocidad } \\
\text { roura (Nis) } \\
\text { Breaking velocity }\end{array}$ \\
\hline $\begin{array}{c}\text { Blanca } \\
\text { White }\end{array}$ & $\begin{array}{l}44-76 \\
(\min -\max )\end{array}$ & 300 & $15,7\left(10-14 \int_{0}\right) \quad 300$ & $2 \cdot 3$ & 70 & & & $\begin{array}{l}2,4-6 \\
\text { (min-max) }\end{array}$ & 300 & & \\
\hline $\begin{array}{l}\text { Nodular } \\
\text { Nodular }\end{array}$ & 41,4 & 300 & $15,8\left(12.177_{x}\right) \quad 300$ & 11,5 & $70-50$ & & & 3,4 & 300 & $2,8(7 \%)$ & 300 \\
\hline $\begin{array}{l}\text { Rayada } \\
\text { Striped }\end{array}$ & 44,9 & 300 & $12,2(9-13) ; 00$ & $\begin{array}{l}* 9 \\
+15.4\end{array}$ & 70 & $\begin{array}{r}* 2,8(6-8 \%) \\
+4,5(5-7 \%)\end{array}$ & $\begin{array}{c}70-50 \\
70\end{array}$ & $\begin{array}{l}3,5-5,6 \\
\text { (min-max) }\end{array}$ & $1300-300$ & $2,4(7.8 \%)$ & 1300 \\
\hline$\underset{\text { Brown }}{\text { Marrón }}$ & 44 & 300 & 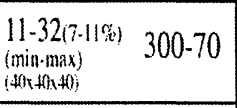 & $\begin{array}{r}* 3,2-8,8 \\
+6,2-11,2 \\
(\text { min-maxi) } \\
\end{array}$ & 70 & & & $\begin{array}{l}3,2-5,6 \\
(\min -\max )\end{array}$ & 300 & & \\
\hline$\underset{\text { Red }}{\operatorname{Roja}}$ & 26 & 300 & $5,2(1+1.158) \quad 70$ & 9,6 & 70 & $1,18.148$ & 70 & 1,5 & $1300-300$ & & \\
\hline
\end{tabular}

Dirección del esfuerzo: $\left({ }^{*}\right)$ Paralelo a las venas y/o grietas, y $(+)$ perpendicular a las mismas.

Direction of force: $(*)$ parallel to veins and or cracks, and $(+)$ perpendicular to the same. 
se ha tenido que desestimar al no soportar, la mayor parte de las probetas, la fuerza mínima aplicada. Los valores de resistencia aquí obtenidos permiten englobar estas areniscas dentro del grupo de materiales pétreos de baja resistencia.

\section{CONCLUSIONES}

- Los cinco tipos de arenisca estudiados forman parte de las conocidas "Areniscas de Ciudad Rodrigo" s.l. La variedad Roja supone la arenisca original dominante en la comarca, mientras que las varicdades Marrón, Rayada, Nodular y Blanca son producto de las transformaciones diagenéticas que afectan a esta arenisca original.

- Las variedades más transformadas (Rayada, Nodular y Blanca) son las variedades más empleadas en la construcción del Conjunto Histórico Artístico de Ciudad Rodrigo, ya que ven mejoradas notablemente sus propicdades petrofísicas y su grado de vistosidad y belleza. La escasa presencia de la variedad Marrón en las canteras impide su uso masivo en la construcción a pesar de ser la variedad que mejores resultados físicomecánicos obtiene.

- En conjunto, son materiales de muy alta porosidad, baja resistencia mecánica y gran capacidad de absorción de agua y permeabilidad al vapor. De forma particular, la modificación mineralógica que sufren estas variedades influye en las características petrofísicas de cada una de ellas.

- Comparando las variedades de mayor contenido en carbonato (Marrón y Blanca) con las de mayor contenido en arcilla (Roja y Nodular) se observa que las primeras ofrecen: a) mayor densidad, velocidad de propagación de ultrasonidos y resistencia mecánica y

b) menor porosidad, poder de absorción de agua y permeabilidad.

- En mayor o menor medida, presentan anisotropías estructurales y texturales, como venas y grietas que influyen en la petrofísica, favoreciendo la absorción, la permeabilidad y la rotura, cuando se disponen a favor de las mismas.

- Su microporosidad es elevada y juega un papel importante. El tamaño dominante de poro $(>50 \%)$ se localiza por debajo de $0,2 \mu \mathrm{m}$ de diámetro, en el caso de la variedad Roja original, y de $0,1 \mu \mathrm{m}$, en las cuatro variedades restantes, lo que implica una prolongada permanencia de las soluciones en el interior de dicha porosidad. Esto llega a suponer un grave problema, pues conlleva la existencia de cambios físicos y químicos en el seno de los materiales pétreos que acelera su deterioro externo.

- La saturación en agua de las cinco areniscas reduce significativamente su resistencia a la rotura. En estado to not resist the minimum force applied. The mechanical strength values obtained here allow these sandstones to be encompassed within the group of lowstrength stone materials.

\section{CONCLUSIONS}

-The five varieties of sandstone studied in the present work form part of those known as the "Ciudad Rodrigo Sandstones" s.l. The Red variety is the original sandstone dominating the area, while the Brown, Striped, Nodular and White varieties are the product of diagnetic transformations that have affected the original type.

-The most transformed varieties (Striped, Nodular and White) are those most used for construction of the monumental heritage of this city, since their petrophysical properties and aesthetics are improved considerably. The scanty presence of the Brown variety in the quarries prevents their widespread use in construction even though this is the variety with the best mechanical-physical properties.

-Overall, these sandstones are materials with high porosity, low mechanical strength, high capacity to absorb water and high permeability to water vapour. In particular, the mineralogical change undergone by these sandstones has affected the petrophysical characteristics of all of them.

-On comparing the varieties with the highest carbonate contents (Brown and White) with those that has the highest clay contents (Red and Nodular), it may be seen that the formers have (a) a greater density, ultrasound propagation velocity and mechanical strength, and (b) a lower porosity; water absorption capacity, and permeability.

-To a greater or lesser extent, these sandstones show structural and textural anisotropies, such as veins and cracks/fissures. These affect their petrophysical properties, favouring absorption, permeability and breakage, when the anisotropies are arranged favourably to them.

-Their microporosity is high and plays an important role.

The dominant pore size (>50\%) is situated at below $0.2 \mu \mathrm{m}$ in diameter in the case of the original Red variety and at $0.1 \mu \mathrm{m}$ in the case of the four remaining varieties. This implies a long residence time of the solutions inside the porosity; which may give rise to important problems since it is accompanied by the existence of physical and chemical changes in the bulk of stone material that accelerate their external deterioration.

-Saturation in water of the five varieties of sandstone significantly reduces their strength to breakage. In the 
seco, las cuatro variedades pétreas producto de la transformación diagenética son las que más resistencia ofrecen a la rotura.

\section{AGRADECIMIENTOS}

Muchos de los resultados presentados en este trabajo han sido posibles gracias a la ayuda, motivación y coraje de la Dra. M. A. Vicente Hernández, fallecida en abril de 2000. Éste es un homenaje a su memoria. El trabajo ha sido financiado por los proyectos "CYCIT" MAT2000-0972-C02-01 y "CS" 12/98. dry state, the four stone varieties derived from the diagenetic transformation of the original type are those with the greatest strength to breakage.

\section{ACKNOWLEDGEMENTS}

Many of the results presented in this work have been possible thanks to the help, motivation and courage of Dr. M. A. Vicente Hernández, who died in april 2000. This is homage to her memory. The work has been supported by the project "CICYT" MAT2000-0972-C02-01 and the project "CS" 12/98.

\section{BIBLIOGRAFÍA}

(1) Varas, M.J. Estudio de los materiales pétreos más empleados en la construcción y sucesivas restauraciones de los edificios de interés histórico de Ciudad Rodrigo, Salamanca. Tesis Doctoral. Dpto. Gcología. Fac. Ciencias. Univ. Salamanca. Inédita. p. 322. Salamanca. 2000.

(2) Alonso, G., Valle, M.F. Paleogeografía del SO de la Fosa de Ciudad Rodrigo (Salamanca). Actas de Palinología (Actas del VI Simposio de Palinología, E.P.L.E.). J.Civis y M.F. Valle, Eds. p. 269-275. Salamanca. 1987.

(3) Cantano, M. Evolución morfodinámica del sector suroccidental de la cuenca de Ciudad Rodrigo. Salamanca. Tesis Doctoral. Univ. Huelva. Inédita. p. 277. Huelva. 1996.

(4) Cantano, M., Molina, E. La cuenca de Ciudad Rodrigo y sus bordes. En: La evolución del relieve en zócalos antiguos: procesos, formaciones superficiales y sedimentos asociados. E. Molina, A. Sánchez y C. Pol, Eds. Stvd. Geol. Salmant. 7: 121-135. Univ. Salamanca. 1999.

(5) Varas, M. J., Molina, E., Vicente, M.A. Areniscas ornamentales empleadas en Ciudad Rodrigo (Salamanca, España): caracterización petrográfica y química de los materiales de cantera. Mater Construcc, vol. 52, n 266: 33-53. Madrid. 2002.

(6) RILEM I-2. Bulk densities and real densities. Paris. 1980.

(7) RILEM II-2. Coefficient de conductivité de vapeur d'eau. Paris. 1978.

(8) NORMAL 7. Assorbimento d'acqua per immersione totale.. Capasitá di Imbibizione. CNR-ICR. Roma. 1981.

(9) NORMAL 11. Assorbimento d'acqua per capillaritá. Coefficiente di Assorbimento Capillare. CNR-ICR. Roma. 1985.

(10) NF, B10-503. Mesures de la porosité de la masse volumique réelle et de la masse volumique apparente. Paris. 1973.

(11) Simmons, G. Ultrasonics in Geology. Proceedings. Inst. Electrical and Electronic Engineers. Vol. 53, nº 10: 1337-1345. London. 1965.

(12) UNE 22-175. Granitos ornamentales. Resistencia a la compresión. IRANOR. Madrid. 1985.

(13) UNE 22-950. Propiedades mecánicas de las rocas. Ensayos para la determinación de la resistencia a la compresión uniaxial. Parte 1. AENOR. Madrid. 1990.

(14) Carmichael, R.S. Handbook of physical properties of rocks. Vol. III, CRC Press, p.340. 1982.

(15) UNE 22-176. Granitos ornamentales. Resistencia a la flexión. IRANOR. Madrid. 1985.

(16) UNE 22-186. Mármoles y calizas ornamentales. Resistencia a la flexión. IRANOR. Madrid. 1985.

(17) UNE 83-306. Ensayos de hormigón. Rotura por tracción indirecta (Ensayo Brasileño). IRANOR. Madrid. 1985.

(18) UNE 22-950. Propiedades mecánicas de las rocas. Ensayos para la determinación de la resistencia a tracción.

Determinación indirecta (Ensayo Brasileño). Parte 2. AENOR. Madrid. 1990.

(19) Zezza, F. Influence of mechanical anisotropic behaviour to tensile strength on decay' evolution of marbles in monuments. Proc. Int. Cong. RILEM-UNESCO "Conservation of stone and other materials". M.J. Thiel, Ed. Vol. I: 220-227. Paris. 1993.

(20) Pédro, G., Delmas, A.B. Regards actuels sur les phénomènes d'alteration hydrolitique. Cahiers ORSTOM, sér. Pédologie, 18 (3-4): 217-234. Paris. 1983.

(21) Pédro, G. Géochimie, minéralogie et organisation des sols. Aspects coordonnés des problèmes pédogénétiques. Cahiers. ORSTOM, sér. Pédologie., 23 (3): 169-187. Paris. 1987.

(22) Pédro, G. Un phénoméne naturel de la surface de la planéte: l'altération des roches. In: Alteraciones de granitos y rocas afines. M. A. Vicente, E. Molina y V. Rives, Eds. C.S.I.C., Madrid. Spain. p. 17-50. 1993.

(23) Farmer, I. Engineering properties of Rock. Spon. London. 1968.

(24) Farmer, I. Engineering behaviour of rocks. Chapman and Hall. p. 208. 1983.

$$
* * *
$$

